Review Paper http://ajol.info/index.php/ijbcs http://indexmedicus.afro.who.int

\title{
Socio-demographic and economic characteristics, crop-livestock production systems and issues for rearing improvement: A review
}

\author{
Daniel Bignon Maxime HOUNDJO ${ }^{1}$, Sébastien ADJOLOHOUN ${ }^{1 *}$, \\ Basile GBENOU ${ }^{1}$, Aliou SAIDOU ${ }^{2}$, Léonard AHOTON ${ }^{2}$, Marcel HOUINATO ${ }^{1}$, \\ Soumanou SEIBOU TOLEBA ${ }^{1}$ and Brice Augustin SINSIN $^{3}$ \\ ${ }^{l}$ Département de Production Animale, Faculté des Sciences Agronomiques, \\ Université d'Abomey-Calavi, 03 BP 2819 Jéricho, Cotonou, Benin. \\ ${ }^{2}$ Département de Production Végétale, Faculté des Sciences Agronomiques, \\ Université d'Abomey-Calavi, 03 BP 2819 Jéricho, Cotonou, Benin. \\ ${ }^{3}$ Département de l'Aménagement et Gestion des Ressources Naturelles, Faculté des Sciences Agronomiques, \\ Université d'Abomey-Calavi, 03 BP 2819 Jéricho, Cotonou, Benin. \\ *Corresponding author; E-mail : s.adjolohoun@yahoo.fr; Tél: (+229) 97898851
}

\begin{abstract}
This paper reviews some characteristics of crop-livestock production systems in Benin with a special focus on the issues for enhance pasture production and nutritive value which in turn will increase animal productivity. Benin is located in the Gulf of Guinea of the Atlantic Ocean in West Africa and covers 114,763 $\mathrm{km}^{2}$. The population estimated in 2017 is 10,900,000 inhabitants with an annual population growth rate of $3.5 \%$. The country is primarily an agro-based economy, characterized by subsistence agricultural production that employs more than $70 \%$. The climate ranges from the bimodal rainfall equatorial type in the south to the tropical unimodal monsoon type in the north. The climatic limiting factor for plant growth is rainfall which is generally tending to diminish with increasing variation between years. There are two main soil types in Benin (ferruginous and ferralitic). Based on a national livestock survey in 2016 the national herd is estimated to be 2339000 cattle (Bos taurus or B. indicus), 915000 sheep (Ovis aries), 1836000 goat (Capra hircus), 466000 swine (Sus scrofa), 2000 equines (Equus caballus), 800 donkeys (E. asinus), 20 camels (Camelus dromedarius) and 20000000 poultry (mainly Numida meleagris). The growth of the ruminant livestock improvement has been impeded by several constraints such as low feed supply in quantity and quality, low crop-livestock integration, low level of management practices, lack of improved breeding stock, disease, inadequate stock water, poor marketing and lack of capital. Zootechnical performances of animals are very low. In this context, the introduction of legume forage would be a sustainable way as it can enhance pasture production and nutritive value which in turn will increase animal productivity.
\end{abstract}

(C) 2018 International Formulae Group. All rights reserved.

Keywords: Benin, agriculture, livestock, feed, grassland.

\section{INTRODUCTION}

In Benin, agriculture is characterized by the traditional predominance of a mixed farming system of crop production and livestock rearing. Agriculture is a major source of income providing employment and livelihoods for rural families. It is also the backbone in rural areas, providing a source of 
employment and the ultimate livelihood for $70 \%$ of the population of rural people and contributing $40 \%$ to National Gross Product (INSAE, 2015).

In the country, land cropping is practised by small-farmers according to the traditional method of slash-and-burn cultivation. Crop productions are commonly severely limited by a shortage of inputs, recurrent droughts and limited soil fertility (Adjolohoun, 2008). The evolution of this form of agriculture is classic in West Africa, as well as in other developing countries. It leads to an increase of cultivated lands to the detriment of the fallowed areas and the natural savannah's (Koura, 2015). The fields are cropped for 3 to 4 years and, afterwards, the land is left in a weed fallow with many unpalatable species for livestock (Adjolohoun, 2008). In this form of land use system, crop and livestock production are weakly interlinked (Koura, 2015). In the other hand, during 2016, Benin animal sector is around 5.09 million ruminants, 0.466 million swine and 20 million poultry which is expected to grow at a rate of between 2.20 and $2.78 \%$ for cattle and small ruminants respectively and $4.44 \%$ for swine (DSA, 2017).

Livestock production system is based on feeding grazing resources which is mainly composed of annual foraging on natural pasture and forest lands. Substantial amount of feeds are also derived increasingly from crop residues, agro industrial by-products and other farm products. The proportional contribution of these feeds however, varies with location and season.

Over the last decades, the crop and livestock system production of the country experienced rapid change in land use/land cover mainly due to increase in human population pressure and partly due to climate change (Koura, 2015). In some parts, over the last five decades, the area under crop cultivation has expanded considerably by about $25 \%$, while that of grassland has contracted greatly by about $30 \%$ (Adjolohoun, 2008). This has resulted in to a considerable change both in the type and the amount of feed available to the livestock keepers.

This paper gives a review of the 1) socio and economic characteristics of Benin, 2) its climatic conditions and ecological zones, 3) summarize agriculture and livestock production systems and 4) propose actions to rehabilitate grass-land areas.

\section{BENIN LOCATION}

Benin is the name which replaced the former colonial Republic of Dahomey after the Revolution of October 26, 1972. Located in the Gulf of Guinea of the Atlantic Ocean, it lies within latitude $6^{\circ} 20^{\prime} \mathrm{N}$ and $12^{\circ} 30^{\prime} \mathrm{N}$ and $1^{\circ} \mathrm{E}$ and $4^{\circ} \mathrm{E}$ with an altitude varying from 0 to $600 \mathrm{~m}$. The country extends on $700 \mathrm{~km}$ from the north to the south and on $125 \mathrm{~km}$ from the East to the West on the coastline of the country. It is a landlocked country in the south of West Africa which borders Niger and Burkina Faso republics to the north, Atlantic Ocean to the south, republic of Nigeria to the east and republic of Togo to the west (Figures 1 and 2). The country covers $114,763 \mathrm{~km}^{2}$, the capital is Porto-Novo and the official language is French.

\section{SOCIO-DEMOGRAPHIC CHARACTERISTICS}

According to the most recent census (INSAE, 2008) the population estimated in 2017 will be 10,900,000 inhabitants with an annual population growth rate of $3.5 \%$, characteristic of most West African countries. Life expectancy at birth is 60 years. It has great ethnic diversity with more than twenty groups of which the main ones are: Fon (25\%), Aja (10\%), Yuruba (10\%), Gun (8\%), Ayizo (05\%) and Toli $(02 \%)$ in the south and the center of the country: Batsnu (14\%), Dendi (08\%), Moksle (04\%), Fulbe (3\%), Husa (02\%), Otamari (02\%), Natcnba (01\%), Wuama (01\%) and Youm (01\%) in the north (Nonfon, 2015). The remaining 4\% is made up of minor ethnic groups. Benin population is predominantly in traditional religion generally called Animism (48\%), Christianity (35\%), Islam (17\%) (Nonfon, 2015). 
Population density is highly variable according to the regions. It is highest in the south of the country (about 100-200 per $\mathrm{km}^{2}$ ) and lowest in the north (about 15-60 per $\mathrm{km}^{2}$ ). Average $70 \%$ of the population is rural (INSAE, 2008; Azuka et al., 2015).

\section{SOCIO-ECONOMIC CHARACTERISTICS}

For human development index, the country rank was 159 and 167 among the 173 countries in 2003 and 2016, respectively. The standard of living is very low; according to UNDP (PNUD, 2000), 75\% of the people are below the poverty line and of which $30 \%$ in extreme poverty. Benin's Gross National Product (GNP) per inhabitant is 380 \$ US. Agriculture contributes 54\% of Benin's GNP and accounts for over $40 \%$ of export earnings while at the same time providing over $90 \%$ of the food needs of the country. Unemployment to population ratio is $32 \%$. The country is primarily an agro-based economy, characterized by subsistence agricultural production that employs more than $70 \%$ of the population. About $65 \%$ of the labour forces are engaged in agriculture, $30 \%$ in services and $2 \%$ in industry. Approximately, 39\% of farm labour forces are women (INSAE, 2015).

\section{CLIMATE AND AGRO-ECOLOGICAL ZONES}

Benin's climate is influenced by the hot, dry and dusty-laden air mass that moves from the north-east across the Sahara and by the tropical maritime air mass that moves from the south-west across the southern Atlantic Ocean. According to ASECNA (2010), the climate ranges from the bimodal rainfall equatorial type in the south to the tropical unimodal monsoon type in the north. The mean monthly temperature over most of the country never falls below $26{ }^{\circ} \mathrm{C}$, a consequence of the low latitude position of Benin and the absence of high altitude areas. Mean annual temperature averages $27{ }^{\circ} \mathrm{C}$. Absolute maxima approach $40{ }^{\circ} \mathrm{C}$, especially in the north, with absolute minima descending to about $15{ }^{\circ} \mathrm{C}$ during harmattan. In the coastal areas, where the modifying influence of the sea breeze is felt the annual range of temperature is between 25 and $26{ }^{\circ} \mathrm{C}$. In the interior on the other hand, the range is higher, about $27^{\circ}$ to $29^{\circ} \mathrm{C}$ (ASECNA, 2010). The rainfall generally decreases from the south to the north. The wettest area is the extreme south-west where the rainfall is over $1300 \mathrm{~mm}$ per annum. In the extreme north, the annual rainfall is on average $900 \mathrm{~mm}$. Much of the rain falls in intense storms of short duration, especially at the beginning of the season resulting in heavy runoff and erosion. The annual mean relative humidity is about $80 \%$ in the south and $55 \%$ in the north (ASECNA, 2010). The climatic limiting factor for plant growth is rainfall which is generally tending to diminish with increasing variation between years for most West African countries (Kagoné, 2000; Adjolohoun, 2008; Diarra et al., 2017). These characteristics have to be taken into account in research and development programs so as to anticipate food and forage crises.

\section{Soils and Topography}

According to Adam and Boko (1983), Youssouf and Lawani (2002), there are four soil types in Benin. These are: ferruginous soils; ferralitic soils; poorly evolved soils; hydromorphic soils and vertisols. The first two soils cover more than two thirds of the country. Ferruginous soils cover the greatest areas. These soils cover generally the center and the north of the country. They have sandy texture and are regularly associated with gravelly soils. Ferralitic soils are found in the south of the country. Their area is very limited. Their profile is related to that of ferruginous soils but their physical and chemical properties are clearly different. Poorly evolved soils are mostly found in the northern half of the country. They are found over the granites and migmatites from which they are derived. Hydromorphic soils are found on river alluviums or on fine weathered material. They have poor drainage and are regularly waterlogged in the rainy season. They are mostly developed in the west of the 
country and are aligned with the drainage network of the main valleys. Vertisols have approximately the same textural parentage as the Hydromorphic soils. All of these types have a poor cation exchange capacity and therefore need appropriate soil management for plant mineral nutrition.

Soil chemical characteristics are variable. According to FAO (1965) and CPCS (1967) soil classification, ferruginous tropical soils in the north of the country are skeletal chromic-luvisoil or tropical concretionary soil (Youssouf and Lawani, 2002). Most lands have a slope varying from 1 to $10 \%$, sometimes with a slightly undulating topography and granite or gneiss as parent material. Soil texture consists of friable gravely sand to gravely sand-loam and is highly leached in most of the region. Their deepness is highly variable $(0.40-2 \mathrm{~m})$ with reddish colour more pronounced in some sites and they increase in ferruginous gravel content with deep. Soils have a low waterholding capacity and are generally medium to well drained. The reaction is slightly acid to neutral $\left(\mathrm{pH}_{\text {water }} 6.0-6.7\right)$ in the surface layers $(0-20 \mathrm{~cm})$, decreasing slightly to acid in the lower layers. The chemical composition of these substrates shows an accumulation of ferric oxides and hydrates with low concentrations of aluminium oxide and low exchangeable cations capacity (2-8 $\mathrm{cmol}^{+} / 100 \mathrm{~g}$ ), but with high base saturation $(80-95 \%)$. Organic matter content is very low $(0.5-1.5 \%)$ and soils are deficient in $\mathrm{N}(0.01$ $0.03 \%)$ and assimilable $\mathrm{P}$ (1-3 ppm Bray) (Youssouf and Lawani, 2002; Azuka et al., 2015).

The topography of the country is mainly a peneplain crystalline covers most area with numerous hills. This peneplain is deeply dissected by the valley of Lama which cut it into two blocks. Follow plateaus which are located mostly in the south of the country with altitude between 20-200 m. The highest region of the country is the mountain of Atacora (600 m).

\section{VEGETATION AND PRODUCTION SYSTEMS}

CROP

According to the Ministry of Agriculture, Livestock and fisheries (MAEP, 2010), the country's land resources are approximately divided as follows: cultivable land $60 \%$ of which only $10 \%$ are under cultivation and $75 \%$ under grazing; protected areas (forests, reserves, national parks) 20\%, other lands (buildings, homesteads, roads, river, etc.) $20 \%$. It should be noted that this distribution of land is not static. Agricultural land is increasing at approximately $3 \%$ annually at the expense of the grazing land (MAEP, 2010). In fact, grazing lands are lands which are not under cultivation and include fallows, marginal lands and reserved lands. The ever increasing demand of farmland, fuel wood and charcoal production coupled with population growth has accelerated the rate of forest reduction in Benin as in most countries of West Africa (Kouelo et al., 2016; Gnikplepko, 2016; Zoumarou et al., 2016; Ye et al., 2017; Enbakom et al., 2017).

Benin's farming systems vary with agro-ecological zone. However, certain general features are discernible throughout the country. This agriculture is predominantly smallholder, traditional in rain-fed conditions with simple tools and, sometimes in the north of the country, animals drawn implements in cotton fields (DSA, 2017). Land is cropping according to slash-and-burn cultivation method for 2 to 3 years and, afterwards, the land is left in a weed fallow with many unpalatable species (Adjolohoun, 2008). Originally, the fallow duration ranged from 10 to 20 years in the country (Floret and Pontanier, 1999), while in other Soudanian zones of West Africa fallow periods up to 30 years are reported (Klein and César, 1999; Somé et al., 2007). Today, the increased population densities and the development of cash crops have drastically reduced land availability, leading to a net reduction of the fallow period with dramatic consequences on soil fertility (Koutika et al., 2002; Nikiema, 2005; Saidou, 2006; Kouelo et al., 2013; 
Koura, 2015). Tables 1, 2, 3, 4, 5 and 6 present vegetable production for cereals, tubercules and roots, leguminous food crop, legumes food crop, horticultural crops and cash crops productions respectively (DSA, 2017). Cereal staple food crops are maize (Zea mays), sorghum (Sorghum bicolor), pearl millet (Pennisetum glaucum) and legume crops are groundnut (Arachis hypogaea) and cowpea (Vigna unguiculata). Rice (Oryza sativa) is cultivated on limited areas corresponding to hydromorphic soils. Pepper (Capsicum annuum), tomato (Lycopersicon esculentum) and bitter-leaf (Vernonia amygdalina) are sometimes grown around the houses. Tomato is one of the most important productions in Benin (Doussoh et al., 2017). Tuber and root crops are yam (Dioscorea batatas), cassava (Manihot esculenta) and sweet potatos (Ipomoea batatas). Clearing starts around January and February and tilling is done between March and April. Planting starts with the rains, between April and May, but installation of some later varieties of yam might take place already in December. Harvesting happens between August and December (Adjolohoun, 2008, Kouelo et al., 2016).

\section{LIVESTOCK RESOURCES}

Based on a national livestock survey in 2016, the national herd is estimated to be 2339000 cattle (B. taurus or B. indicus), 915 000 sheep $(O$. aries), 1836000 goat $(C$. hircus), 466000 swine (S. scrofa), 2000 equines (E. caballus), 800 donkeys $(E$. asinus), 20 camels (C. bactrianus) and 20000000 poultry (mainly N. meleagris). Over the last decade, annual increases are $2.7 \%$ for cattle, $15 \%$ for swine and $3 \%$ for small ruminants (DSA, 2017). Table 7 shows livestock number and production data for Benin from 1970 to 2016. During the last decade, total meat, milk and eggs production varied between 39500 and 71990 tons, 80089 and 115000 tons and 7445 and 16006 tons per year, respectively. Cattle, poultry, small ruminants and swine contribute about 57\%, $20 \%, 13 \%$ and $8 \%$ to total meat production
(DSA, 2017). According to FAO (2014), the requirement needs of meat for the population of the country would be 143000 tons in 2020 and only $50 \%$ of this will be produced in the country. Therefore, the import of more than 70000 tons of meat would be necessary to meet the requirement of the population.

\section{Cattle}

Many cattle breeds are reared in Benin. The most important in term of number is Zebu $\times$ Borgou accounts for $35 \%$ of the total country cattle livestock. It is a natural cross between Zebu and Borgou and is found mainly in the Center and North of Benin. Followed by Borgou breed (27\%) of the livestock is encountered particularly in the South of Borgou and East of Atacora regions (DE, 2013). The breed Borgou $\times$ Somba accounts for $14 \%$ is found in Atacora region. Borgou $\times$ Lagunaire breed $(11 \%)$ is found in the Center and South of the country. Zebu breed $(8 \%)$ and Lagunaire breed $(4 \%)$ are found in North and South of the country, respectively. Somba breed is the least represented $(<1 \%)$. The Borgou is a natural cross between the West African Short (Lagunaire) and the large humped Zebu cattle. It has developed a degree of tolerance to tsetse-borne trypanosomiasis (DE, 2013). The Zebu cattle are susceptible to trypanosomiasis and are found mainly in tsetse fly free areas. Zootechnical performances of these animals are presented in Table 8 . The poor quality and instability of the native pasture lead to a low nutritive value of forages and increase calf mortality, the mortality rates from birth to weaning are about 35 to $45 \%$ (Table 8 ).

\section{Sheep}

The major sheep breed, the indigenous West African Dwarf (WAD) or Djallonké breed is distributed nation-wide. The breed is acknowledged for its hardiness, trypanotolerance, prolificacy and suitability for year-round breeding. Although it is a small animal, with an adult weight of $15-25 \mathrm{~kg}$ in males and 15-20 kg in females, the Djallonké does not exhibit traits associated with 
dwarfism (DE, 2013). The larger and longlegged Sahelian sheep, and crosses between the Djallonké and the Sahelian sheep, are found mostly in the north of the country and peri-urban areas. The low feed supply in quantity and quality increases lamb mortality, the mortality rates from birth to weaning are about 15 to $40 \%$ (Table 8 ).

\section{Goats}

Most goats in Benin are of the indigenous WAD breed. The adult male weighs $15-22 \mathrm{~kg}$ and the female $15-20 \mathrm{~kg}$. The breed is very prolific, precocious and trypanotolerant and are found throughout the country (DE, 2013). There are considerable numbers of the much larger and long-legged and exotic Sahelian as well as crosses between the WAD and the Sahelian goats in the north of the country and in the peri-urban areas. The productivity of the livestock is very low, the mortality rates from birth to weaning are about 15 to $40 \%$ (Table 8).

\section{Ruminants}

In Benin, ruminant livestock improvement has been impeded by several constraints such as low feed supply in quantity and quality, low crop-livestock integration, low level of management practices, lack of improved breeding stock, disease, inadequate stock water, poor marketing and lack of capital (Adjolohoun, 2008). Among these difficulties, the first is cited to be the most important. Livestock owners in their search for ruminant feeds intensively overexploit the natural vegetation as well as the weed fallows, and the availability of the natural forage has currently become the main constraint to ruminant production as in most West African countries (Peters and Lascano, 2003; Carr et al., 2005; Adjolohoun, 2008; Koura, 2015, Gimenes et al., 2017). This is especially the case during the dry season when the low nutritive value of forages induces loss of ruminants body weight, reduces milk production and increases calf mortality as well as nutritional anoestrus (McIntire et al., 1992; Gbamboché, 2005). The productivity of the livestock is very low, well below their potential and there is room for improvement (Table 8). There is an urgent need to adopt grassland improvement practices to maintain the quantity and quality of grasslands.

\section{ANIMAL MANAGEMENT SYSTEMS}

Although transhumant, pastoralists, nomadic and semi-nomadic tribes are crossed through Benin land, the main production system is based mainly agro-pastoralism system on extensive grazing or free range among smallholder farmers. After crop harvest, all members of the community have the right to graze their stock on any farmland, and grazing land (natural pasture) is generally communally owned (Lesse, 2016).

\section{Agro-pastoralism}

The smallholder agro-pastoralism, the main cattle production system in Benin, is geared towards beef production. It is linked with milk production system whereby milk is shared between the herdsman and the calf, with the surplus going to the market (Gnikplepko, 2016). In this system, settled farmers whose main occupation is crop cultivation own livestock. Ownership may be direct, personal and individual, or in the form of trusteeship for family group property held in trust. Where a large herd is found the owning family group may be several, varying widely in size and in relationship. It frequently occurs that the apparent owner is not the sole owner and he is unable either to authorize or approve extensive interventions without consultation with the co-owners (DE, 2013). The practice of herding under smallholder agro-pastoralism has not changed over decades. It has been described by Gnikplepko (2016) as a function of the type of settlement and distribution of the community, influenced by the availability of water and quantity of grazing areas.

\section{Integrating livestock with tree crop plantations}

There is a long history of integrating livestock into farming systems in Benin, the 
major one being rearing of cattle and sheep under tree crop plantations. This is mainly found in coastal region of the country on oil palm, citrus and coconut plantations (DE, 2013). Introduced forage species of Panicum maximum, Brachiaria deflexa, B. lata, Andropogon gayanus, Centrosema pubescens and Pueraria

phaseloides constitute the main diet of these animals in the plantations. However, a wide range of volunteer forbs and grasses, such as Aspilia africana, Asystasia gangetica, Euphorbia hirta, P. laxum and Phyllanthus muellerianus contribute significantly to the forage biomass. Farmers who have adopted the technology of integrating livestock with tree crops show lower standards of stock husbandry than the agro-pastoralists (DE, 2013).

\section{Backyard small ruminant rearing}

Backyard small ruminant rearing is popular in peri-urban areas. In this system, simple pens are usually provided for sheep and goats within or attached to the owner's house (DE, 2013). The pens are constructed from locally available materials such as timber offcuts, bamboo, tree branches and mud, and roofed with leaves, split bamboo or metal sheets. Children often undertake daily management, such as provision of water, feed and bedding as well as cleaning of pens. The system is based on cut and carry of forages, and the use of household wastes, mainly cassava and yam peels, crop residues and crop by-products. Breeding is normally not controlled and the animals are therefore open to conception as soon as puberty is attained (DE, 2013). Due to limited access to veterinary services, curative "self-medication" is commonly practised at times using various herbal concoctions (Olounladé, 2011). The backyard system supplies fattened rams and bucks for the expanding urban market, particularly during religious festivities.

\section{Ranching}

There are also four farms (Okpara, Bétécoucou, Samiondji and Kpinou) belonging to state institutions with herds ranging from 500 to 3000 cattle (DE, 2013). In this system, cattle graze on sown pastures as well as natural pastures, which are sometimes improved with forage legumes. Introduced forage species of $P$. maximum local and $P$. maximum $C 1, B$. ruziziensis, $A$. gayanus, $C$. pubescens, Stylosanthes hamata, Leucaena leucocephala and Gliricidia sepium. The system represents a comparatively safe, automatically incremental and readily realizable investment.

\section{Poultry production system}

In Benin, poultry is raised in traditional free-range system which accounts for about $97 \%$ of the poultry population of the country and are kept by smallholders (DE, 2013; DSA, 2017). In this system, different species are kept and the most important being chickens, guinea fowls, ducks and pigeons. Flock sizes vary from an average of 1-10 birds of indigenous poultry per rural household (Nonfon, 2015). The birds are owned mostly by women and children for home consumption, small cash income, social and cultural activities. These are left to scavenge around the homesteads during daytime feeding on household leftovers, waste products and environmental materials such as insects, worms, seeds and green forages. In addition, the birds are not regularly provided with water and other inputs such as supplementary feeds, houses, vaccination and medication. As a consequence, many birds die during pre-weaning periods due to starvation, diseases and predators. The level of productivity in terms of number of eggs produced (30-50 eggs hen ${ }^{-1}$ year $^{-1}$ ) and growth rate $\left(5-10 \mathrm{~g} \mathrm{day}^{-1}\right)$ (Smith, 1990; Guèye, 1998; DSA, 2017) is very low compared with semiintensive or intensive systems.

\section{FEED RESOURCES}

In Benin, ruminants are maintained throughout the year on natural pastures comprised largely of grasses which nutritional value decreases very rapidly during the dry season (Adjolohoun, 2008; Adjolohoun et al., 
2013a; Gnikplekpo, 2016). Feeding animals remains the major constraint for productivities improvement in ruminant production (Adjolohoun, 2008; Koura, 2015). Natural fallows and savannahs constitute the basic feed for ruminants. Legume species are poorly represented in these grasslands, which are largely dominated by native grasses and weeds (Buldgen et al., 2001; Adjolohoun, 2008). Ligneous species available are Afzelia africana, Khaya senegalensis, Pterocarpus erinaceus, Parkia biglobosa and Elaeis guineensis (Houinato, 2001).

\section{Natural pastures}

The growth pattern of the forages follows the rainfall pattern within the different agro-ecological zones. In the Coastal Savannah area, there is a growing season of seven months and a "non-growing" period of five months while in the Northern Savannah area, the growing season lasts for six months and the "non-growing" period for equally length. The annual total dry matter yields reduced continuously over the years and vary between 0.3 and 2.5 tons dry matter per ha per year through the country (Sinsin et al., 1989; Adjolohoun, 2008; Lesse, 2016). On this basis of potential grazing land existing in the country reported above by MAEP (2010) and the grassland productivity of about $500 \mathrm{~kg}$ dry matter per ha and per year reported by many authors (Atchadé and Sidi 1990; Adjolohoun, 1992; Adandédjan, 1993; Adjolohoun, 1994; Houinato 2001; Adjolohoun 2008; Lesse 2016), edible annual grass forage available in Benin could be estimated to about $1,000,000$ tons. Main dominant species are Andropogon sp, Panicum sp., Brachiaria sp., Cymbopogon giganteus, Aframomum spp, Hyparhenia spp., Paspalum scrobiculatum, Loudetiopsis ambiens, Sorghastrum bipennatum, Fuirena ciliaris, Setaria sphacellata, Hyparrhenia rufa, Schizachyrium sanguineum, Schizachyrium schweinfurthuii, etc. (Lesse, 2016).

In both zones, about 80 percent of the yields are achieved within the growing season. The ligneous species within the natural pastures are estimated to give forage dry matter (DM) yield of about 200-500 $\mathrm{kg} / \mathrm{ha} /$ year (Adjolohoun, 1992). The nutritive value of the natural pasture herbage varies over the year according to the season. Protein content is high (8-12 percent DM) at the beginning of the rains but may drop to as low as 2 to 4 percent DM in the dry season (Adjolohoun et al. 2013a). Phosphorus levels are also low and rang between 0.06 and 0.16 percent DM (Buldgen et al., 2001; Adjolohoun, 2008; Adjolohoun et al. 2013a; Montcho et al., 2016).

Bush fires often occur as a result of illegal and uncontrolled burning of bush after harvest to remove rank vegetation, or for hunting or just for fun. The incidence of bush fires can be correlated with human presence, as indeed can cattle density, since fires occur most frequently in areas with very high cattle populations. Damage done by fire to the natural pastures is very significant and is a major contributing factor in the decline in the condition of both natural and sown pastures as well as the greatest constraint to the success of over-sowing natural pasture with forage legumes. Uncontrolled bush fire destroys standing hay and crop residues lying in the field. Although there have been efforts at educating the farming communities against bush burning, the impact has not been very effective, particularly in the Coastal Savannah zone. This may be due partly to lack of collaboration among the sectors in anti-bush fire campaign and inadequate logistic support to fire-fighting volunteers. Whereas a group of anti-bush fire campaigners place emphasis on "early-burning" as a solution to the wanton incidence and the devastating effect of bush fire, others preach "no-burning" concept, which tend to confuse the farmers.

\section{Crop residue}

Crop residues and also tree fodder are commonly used in the dry season (Koura, 2015). However, regarding tree fodders, the legumes trees used are threated and their population decreased. Indeed, exploitation of branches of these trees with even reproduction 
organs limits the regeneration of the species. About 300,000 tons of legumes (groundnut and cowpea) residues are produced in Benin (FAO, 2014).

After harvest, crop residues normally complement standing hay and in some cases take the place of natural grasses in the range in providing the bulk of ruminant feed. In general, cereal and legume residue represents approximately $30-35 \%$ of grain production (Adjolohoun, 1992). On this basis and according to cereal grain production in Benin (Table 1), cereal crop residues can be estimated at about 500,000 tons of cereal stalks and 900,000 tons of residues from roots and tubers are potentially available as animal feed in each year. However, quantities of these that are actually fed to livestock form a very small fraction $(<10 \%)$ of the available crop residues. Large scale systematic feeding of crop residues is hindered by alternative uses such as fuel source (e.g. sorghum and millet stalks), thatching (hut roof), and by the problem of collection in view of the bulkiness of the residue and in some cases distance from settlements. In some cases, many possibilities for using crop residues are ignored by farmers and do not made any attempt to recover from the field, store and improve the quality of these valuable resources. In spite of this, crop residues, such as groundnut and cowpea haulms, bean vines, maize, sorghum and millet stover, cassava or yam peelings constitute the bulk of ruminant feed during the dry season (Koura, 2015; Ojokoh and Odesanya, 2016). Tables 9 and 10 present dry matter content and chemical composition of main crop residues produced in the country. According to Koura (2015), crude protein contents of cereal residues are between 2.44 and $5.84 \%$ and are very below the critical level of 7 to $8 \%$ needed to maintain efficient rumen function (Minson, 1981; Babatounde et al., 2010). Indeed, despite their low nutritive value, crop residues supply feed for livestock in West Africa (Savadogo, 1999; Ayantunde et al., 2007; Attoh-Kotoku, 2011; Akinfemi et al., 2012).

\section{PASTURE \\ IMPROVEMENT: INTRODUCTION OF LEGUMES SPECIES IN PASTURES}

Sustainable models of animal production constantly seek for ways to pasture production with inputs reduction. In this context, the introduction of forage legumes in the pasture system is fundamental to fix nitrogen from the atmosphere and supply it to grasses, increasing its production and persistence, enhancing animal nutrition (Adjolohoun et al., 2013c; Flávia et al., 2017). In tropical areas such as Benin, forage grasses grow rapidly and plentiful biomass is produced after the onset of the rains, but protein concentration declines as grasses grow and mature. During the dry season, the crude protein concentration in the native grasses can drop below 3\% DM (Adjolohoun 2008, Koura, 2015). To solve this problem, livestock farmers can supplement their livestock with agro industrial by-products such as cottonseed and groundnut cake, but this solution is costly. As an alternative, cultivated forage legumes can provide cheap high-quality feed, which can greatly enhance the productivity of traditional agricultural systems. Owing to their higher $\mathrm{N}$ content compared with grasses, legumes improve intake of forage by ruminants and digestion of fiber and reduce $\mathrm{CO}_{2}$ and methane emissions from the rumen, through a more efficient use of the energy content of the ingested forage (Mannetje, 2000). Tables 11, 12, 13 and 14 report a number of forage legumes which can be used to improve pasture productivity and nutritive values. Their integration in crop rotations may also increase grain yields of the subsequent food crops $(25-136 \%)$ and potentially save $50-300 \mathrm{~kg} / \mathrm{ha} \mathrm{N}$ of artificial fertilizer (Cook et al., 2005). 


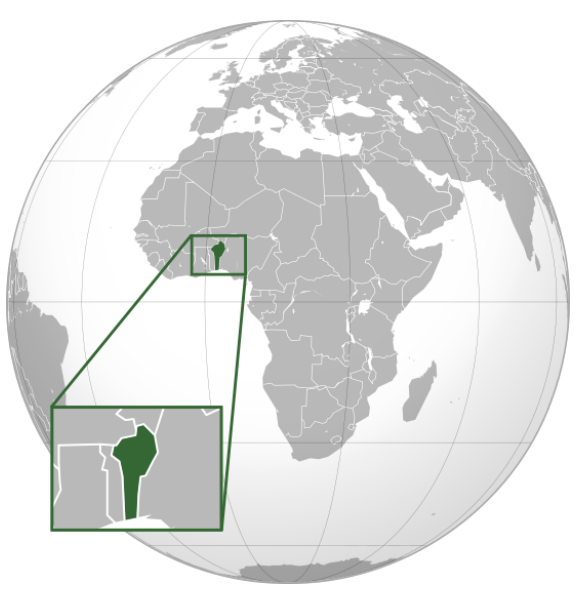

Figure 1: Location of Benin in West Africa.

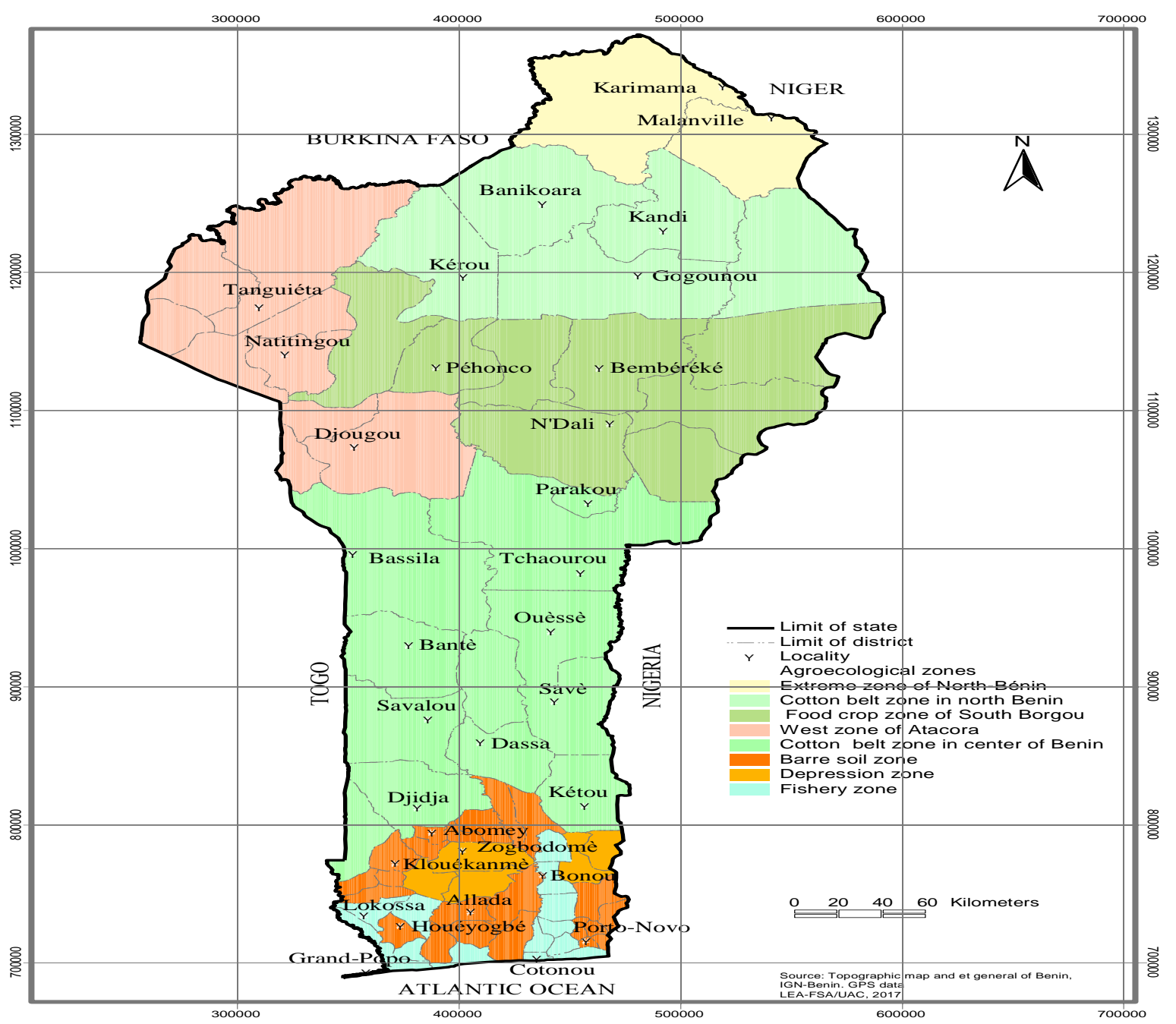

Figure 2: Benin map and agro-ecological zones (IGN, 2017). 
Table 1: Benin cereal food crop production.

\begin{tabular}{lccccccccccc}
\hline & \multicolumn{10}{c}{ Year } \\
\cline { 2 - 11 } Crop & \multicolumn{2}{c}{$\mathbf{2 0 0 0}$} & \multicolumn{2}{c}{$\mathbf{2 0 0 5}$} & \multicolumn{2}{c}{$\mathbf{2 0 1 0}$} & \multicolumn{2}{c}{$\mathbf{2 0 1 5}$} & \multicolumn{2}{c}{$\mathbf{2 0 1 6}$} \\
\cline { 2 - 12 } & Area & Yield & Area & Yield & Area & Yield & Area & Yield & Area & Yield \\
& $(\mathbf{h a})$ & $(\mathbf{k g} / \mathbf{h a})$ & $(\mathbf{h a})$ & $(\mathbf{k g} / \mathbf{h a})$ & $(\mathbf{h a})$ & $(\mathbf{k g} / \mathbf{h a})$ & $(\mathbf{h a})$ & $(\mathbf{k g} / \mathbf{h a})$ & $(\mathbf{h a})$ & $(\mathbf{k g} / \mathbf{h a})$ \\
\hline Maize & 644989 & 1210 & 726016 & 1202 & 924764 & 1152 & 968030 & 1399 & 1003715 & 1281 \\
Rice & 17476 & 2112 & 24749 & 2627 & 40834 & 2760 & 74586 & 3139 & 65305 & 3129 \\
Millet & 37950 & 785 & 44761 & 823 & 33998 & 807 & 27724 & 854 & 26670 & 811 \\
Sorghum & 154564 & 812 & 181253 & 905 & 119880 & 1099 & 101513 & 988 & 131553 & 986 \\
\hline
\end{tabular}

Source: (DSA, 2017).

Table 2: Tuber and root food crop production.

\begin{tabular}{|c|c|c|c|c|c|c|c|c|c|c|}
\hline \multirow[b]{2}{*}{ Crop } & \multicolumn{2}{|c|}{2000} & \multicolumn{2}{|c|}{2005} & \multicolumn{2}{|c|}{2010} & \multicolumn{2}{|c|}{2015} & \multicolumn{2}{|c|}{2016} \\
\hline & $\begin{array}{l}\text { Area } \\
\text { (ha) }\end{array}$ & $\begin{array}{c}\text { Yield } \\
\text { (kg/ha) }\end{array}$ & $\begin{array}{l}\text { Area } \\
\text { (ha) }\end{array}$ & $\begin{array}{c}\text { Yield } \\
\text { (kg/ha) }\end{array}$ & $\begin{array}{l}\text { Area } \\
\text { (ha) }\end{array}$ & $\begin{array}{c}\text { Yield } \\
\text { (kg/ha) }\end{array}$ & $\begin{array}{c}\text { Area } \\
\text { (ha) }\end{array}$ & $\begin{array}{c}\text { Yield } \\
\text { (kg/ha) }\end{array}$ & $\begin{array}{c}\text { Area } \\
\text { (ha) }\end{array}$ & $\begin{array}{c}\text { Yield } \\
\text { (kg/ha) }\end{array}$ \\
\hline Cassava & 202117 & 10432 & 237916 & 13187 & 256615 & 14761 & 296641 & 13709 & 284033 & 12044 \\
\hline Yam & 145366 & 9571 & 171746 & 12775 & 167919 & 14135 & 214054 & 14909 & 202605 & 13082 \\
\hline Sweet potato & 10880 & 6327 & 11163 & 4479 & 11442 & 5585 & 10938 & 5987 & 10016 & 5532 \\
\hline Potato & 3 & 533 & 12 & 667 & 11 & 768 & 13 & 1290 & 6 & 1386 \\
\hline Taro & 518 & 4548 & 612 & 4144 & 974 & 2671 & 519 & 3913 & 559 & 2921 \\
\hline
\end{tabular}

Source: (DSA, 2017).

Table 3: Benin leguminous food crop production.

\begin{tabular}{lcccccccccc}
\hline \multirow{2}{*}{ Crop } & \multicolumn{2}{c}{$\mathbf{2 0 0 0}$} & \multicolumn{2}{c}{$\mathbf{2 0 0 5}$} & \multicolumn{2}{c}{$\mathbf{2 0 1 0}$} & \multicolumn{2}{c}{$\mathbf{2 0 1 5}$} & \multicolumn{2}{c}{$\mathbf{2 0 1 6}$} \\
\cline { 2 - 11 } & $\begin{array}{c}\text { Area } \\
\text { (ha) }\end{array}$ & $\begin{array}{c}\text { Yield } \\
\text { (kg/ha) }\end{array}$ & $\begin{array}{c}\text { Area } \\
\text { (ha) }\end{array}$ & $\begin{array}{c}\text { Yield } \\
(\mathbf{k g} / \mathbf{h a})\end{array}$ & $\begin{array}{c}\text { Area } \\
(\mathbf{h a})\end{array}$ & $\begin{array}{c}\text { Yield } \\
(\mathbf{k g} / \mathbf{h a})\end{array}$ & $\begin{array}{c}\text { Area } \\
(\mathbf{h a})\end{array}$ & $\begin{array}{c}\text { Yield } \\
(\mathbf{k g} / \mathbf{h a})\end{array}$ & $\begin{array}{c}\text { Area } \\
(\mathbf{h a})\end{array}$ & $\begin{array}{c}\text { Yield } \\
(\mathbf{k g} / \mathbf{h a})\end{array}$ \\
\hline Bean & 112218 & 664 & 122558 & 767 & 106764 & 826 & 116559 & 822 & 120612 & 822 \\
Groundnut & 125538 & 813 & 160217 & 966 & 147798 & 894 & 163009 & 869 & 15812009 & 850 \\
Soybean & 3234 & 835 & 10173 & 544 & 58225 & 949 & 97783 & 1013 & 152138 & 920 \\
"Voandzou" & 12747 & 1141 & 18581 & 813 & 14862 & 757 & 13250 & 949 & 12619 & 825 \\
\hline
\end{tabular}


Table 4: Benin legume food crop production.

\begin{tabular}{|c|c|c|c|c|c|c|c|c|c|c|}
\hline \multirow[b]{2}{*}{ Crop } & \multicolumn{2}{|c|}{2000} & \multicolumn{2}{|c|}{2005} & \multicolumn{2}{|c|}{2010} & \multicolumn{2}{|c|}{2015} & \multicolumn{2}{|c|}{2016} \\
\hline & $\begin{array}{c}\text { Area } \\
\text { (ha) }\end{array}$ & $\begin{array}{c}\text { Yield } \\
\text { (kg/ha) }\end{array}$ & $\begin{array}{c}\text { Area } \\
\text { (ha) }\end{array}$ & $\begin{array}{c}\text { Yield } \\
(\mathrm{kg} / \mathrm{ha})\end{array}$ & $\begin{array}{c}\text { Area } \\
\text { (ha) }\end{array}$ & $\begin{array}{c}\text { Yield } \\
\text { (kg/ha) }\end{array}$ & $\begin{array}{c}\text { Area } \\
\text { (ha) }\end{array}$ & $\begin{array}{c}\text { Yield } \\
\text { (kg/ha) }\end{array}$ & $\begin{array}{c}\text { Area } \\
\text { (ha) }\end{array}$ & $\begin{array}{c}\text { Yield } \\
\text { (kg/ha) }\end{array}$ \\
\hline Tomato & 20953 & 5435 & 24526 & 5884 & 28078 & 5558 & 45630 & 8779 & 303893 & 7786 \\
\hline Pepper & 17830 & 1302 & 20378 & 2058 & 18235 & 1415 & 28070 & 2706 & 25861 & 2928 \\
\hline Onion & 726 & 15952 & 386 & 10238 & 2418 & 14893 & 2652 & 16155 & 4156 & 17120 \\
\hline "Gumbo" & 12003 & 2662 & 4086 & 4847 & 12945 & 3310 & 14397 & 3397 & 12751 & 3258 \\
\hline "Leaf legume" & 819 & 8873 & 1242 & 9047 & 4403 & 5279 & 10613 & 8593 & 13824 & 13971 \\
\hline
\end{tabular}

Source: (DSA, 2017).

Table 5: Benin horticultural crop production.

\begin{tabular}{|c|c|c|c|c|c|c|c|c|c|c|}
\hline \multirow[b]{2}{*}{ Crop } & \multicolumn{2}{|c|}{2000} & \multicolumn{2}{|c|}{2005} & \multicolumn{2}{|c|}{2010} & \multicolumn{2}{|c|}{2015} & \multicolumn{2}{|c|}{2016} \\
\hline & $\begin{array}{c}\text { Area } \\
\text { (ha) }\end{array}$ & $\begin{array}{c}\text { Yield } \\
(\mathrm{kg} / \mathrm{ha})\end{array}$ & $\begin{array}{l}\text { Area } \\
\text { (ha) }\end{array}$ & $\begin{array}{c}\text { Yield } \\
\text { (kg/ha) }\end{array}$ & $\begin{array}{c}\text { Area } \\
\text { (ha) }\end{array}$ & $\begin{array}{c}\text { Yield } \\
\text { (kg/ha) }\end{array}$ & $\begin{array}{c}\text { Area } \\
\text { (ha) }\end{array}$ & $\begin{array}{c}\text { Yield } \\
\text { (kg/ha) }\end{array}$ & $\begin{array}{r}\text { Area } \\
\text { (ha) }\end{array}$ & $\begin{array}{c}\text { Yield } \\
\text { (kg/ha) }\end{array}$ \\
\hline Lettuce & 2167 & 4356 & 5004 & 6543 & 3289 & 7619 & 4271 & 7614 & 3564 & 8618 \\
\hline Cabbage & 355 & 18760 & 389 & 12896 & 509 & 13666 & 398 & 16867 & 444 & 18125 \\
\hline Carrot & 378 & 13902 & 429 & 16754 & 690 & 14901 & 651 & 14882 & 717 & 15847 \\
\hline Watermelon & 12467 & 15698 & 1544 & 16770 & 967 & 19843 & 1432 & 18753 & 1596 & 17748 \\
\hline Cucumber & 187 & 14699 & 190 & 13581 & 210 & 11631 & 267 & 12098 & 250 & 10643 \\
\hline
\end{tabular}

Source: (DSA, 2017).

Table 6: Benin cash crop production.

\begin{tabular}{|c|c|c|c|c|c|c|c|c|c|c|}
\hline \multirow[b]{2}{*}{ Crop } & \multicolumn{2}{|c|}{2000} & \multicolumn{2}{|c|}{2005} & \multicolumn{2}{|c|}{2010} & \multicolumn{2}{|c|}{2015} & \multicolumn{2}{|c|}{2016} \\
\hline & $\begin{array}{l}\text { Area } \\
\text { (ha) }\end{array}$ & $\begin{array}{c}\text { Yield } \\
\text { (kg/ha) }\end{array}$ & $\begin{array}{l}\text { Area } \\
\text { (ha) }\end{array}$ & $\begin{array}{c}\text { Yield } \\
\text { (kg/ha) }\end{array}$ & $\begin{array}{l}\text { Area } \\
\text { (ha) }\end{array}$ & $\begin{array}{c}\text { Yield } \\
\text { (kg/ha) }\end{array}$ & $\begin{array}{c}\text { Area } \\
\text { (ha) }\end{array}$ & $\begin{array}{c}\text { Yield } \\
\text { (kg/ha) }\end{array}$ & $\begin{array}{l}\text { Area } \\
\text { (ha) }\end{array}$ & $\begin{array}{c}\text { Yield } \\
\text { (kg/ha) }\end{array}$ \\
\hline Cotton & 305236 & 1234 & 156350 & 1046 & 137086 & 999 & 405400 & 970 & 313535 & 859 \\
\hline Cashew nut & 38966 & 1843 & 40988 & 1765 & 49087 & 2109 & 56398 & 1542 & 68166 & 2056 \\
\hline Sugar cane & 553 & 21899 & 505 & 20150 & 437 & 20058 & 460 & 21790 & 810 & 33679 \\
\hline Oil palm & 7007 & 7560 & 7843 & 9005 & 8082 & 8830 & 6584 & 10700 & 12129 & 5950 \\
\hline Pineapple & 1492 & 47233 & 2065 & 58689 & 4208 & 51210 & 6512 & 57592 & 6682 & 53531 \\
\hline Tabaco & 707 & 651 & 874 & 678 & 183 & 508 & 20 & 749 & 28 & 530 \\
\hline
\end{tabular}


D.B. M. HOUNDJO et al. / Int. J. Biol. Chem. Sci. 12(1): 519-541, 2018

Table 7: Benin statistics for livestock numbers, meat and milk production (1970 - 2016).

\begin{tabular}{|c|c|c|c|c|c|c|c|c|c|}
\hline \multirow{2}{*}{ Species } & \multicolumn{9}{|c|}{ Year } \\
\hline & 1970 & 1980 & 1990 & 2000 & 2010 & 2012 & 2014 & 2015 & 2016 \\
\hline Cattle & 500000 & 750000 & 1080000 & 1879000 & 2005000 & 2111000 & 2222000 & 2280000 & 2339000 \\
\hline Sheep & 656000 & 691000 & 726000 & 767000 & 808000 & 842000 & 878000 & 896000 & 915000 \\
\hline Goats & 1216000 & 1286000 & 1360000 & 1434000 & 1605000 & 1678000 & 1755000 & 1795000 & 1836000 \\
\hline Swine & 166000 & 192000 & 222000 & 254000 & 368000 & 398000 & 431000 & 448000 & 466000 \\
\hline Equine & 950 & 1100 & 1250 & 1400 & 1560 & 1700 & 1750 & 1900 & 2000 \\
\hline Donkey & 500 & 545 & 560 & 610 & 629 & 650 & 680 & 730 & 800 \\
\hline Camels & 5 & 8 & 10 & 13 & 15 & 15 & 17 & 20 & 20 \\
\hline Poultry & 10000000 & 12000000 & 12900000 & 15600000 & 17200000 & 17820000 & 19500000 & 19512000 & 20000000 \\
\hline Aulacode & 90000 & 110000 & 150000 & 200000 & 230000 & 250000 & 300000 & 320000 & 350000 \\
\hline Rabbits & 20000 & 25000 & 36000 & 45000 & 58000 & 60000 & 70000 & 74000 & 75000 \\
\hline Meat (tons) & 39500 & 47000 & 53900 & 58358 & 61646 & 64969 & 68492 & 70327 & 71990 \\
\hline Milk (tons) & 80089 & 84560 & 89200 & 94110 & 99334 & 107254 & 110066 & 112958 & 115000 \\
\hline Egg (tons) & 7745 & 8175 & 8623 & 9348 & 9850 & 11551 & 13585 & 14746 & 16006 \\
\hline
\end{tabular}


Table 8: Zootechnical parameters of cattle, sheep and goat.

\begin{tabular}{lcccc}
\hline \multirow{2}{*}{ Parameters } & \multicolumn{3}{c}{ Species } \\
\cline { 2 - 5 } & Cattle & Sheep & Goat & Swine \\
\hline Age at first oestrus (months) & $24-27$ & $16-20$ & $14-21$ & $4-6$ \\
Age at first parturition (months) & $30-50$ & $21-25$ & $20-26$ & $8-11$ \\
Parturition frequency (months) & $15-20$ & $7-10$ & $7-10$ & $5-8$ \\
Fertility (\%) & $80-90$ & $80-95$ & $80-95$ & $90-94$ \\
Sterility (\%) & $10-20$ & $5-20$ & $5-20$ & $6-10$ \\
Reproduction rate (\%) & $70-80$ & $70-85$ & $70-85$ & $85-90$ \\
Abortion rate (\%) & $10-20$ & $10-15$ & $10-15$ & 5 \\
Number of animal per parturition (units) & 1 & $1-1.2$ & $1.2-2.0$ & $4-8$ \\
Mortality rate from birth to weaning (\%) & $35-45$ & $15-40$ & $15-40$ & $30-50$ \\
Adult mortality (\%) & $15-30$ & 15 & 15 & 5 \\
Weight at birthday (kg) & $8-12$ & $0.8-1.5$ & $0.7-1.5$ & $0.6-1.0$ \\
Age of weaning (months)* & $9-15$ & $4-6$ & $4-7$ & 8 (weeks) \\
Weight at weaning (kg) & $40-80$ & $5-7$ & $4-7$ & $1.5-3.0$ \\
Weight at 1 year age (kg) & $40-80$ & $10-12$ & $8-12$ & $15-20$ \\
Adult weight (kg) & $180-200$ & $15-25$ & $15-20$ & $30-40$ \\
Numeric productivity (unit/female/year) & $0.55-0.65$ & $0.9-1.5$ & $1.1-2.6$ & $4-11$ \\
Weight productivity (kg/female/year) & $22-55$ & $9-18$ & $9-20$ & $60-200$ \\
\hline * Week for swine age of weaning; Source: (Adjolohoun, $1994 ;$ Gbanboché $2005 ;$ DE, 2013 $;$ DSA, 2017). &
\end{tabular}

Table 9: Dry matter composition and nutritive values of crop residues in Central regions of Benin.

\begin{tabular}{|c|c|c|c|c|c|}
\hline & DM (\%) & $\operatorname{Ash}(\%)$ & CP (\%) & NDF (\%) & $\mathrm{ME}(K J / \mathrm{kgDM})$ \\
\hline \multicolumn{6}{|l|}{ Cereal } \\
\hline Maize cob & 94.2 & 3.62 & 4.99 & 84.9 & 6.48 \\
\hline Maize husks & 94.4 & 2.52 & 3.31 & 87.4 & 6.31 \\
\hline Maize stalks & 92.9 & 3.25 & 4.40 & 88.1 & 6.38 \\
\hline Sorghum offal & 93.2 & 4.53 & 2.44 & 83.8 & 4.54 \\
\hline \multicolumn{6}{|l|}{ Legume } \\
\hline Cowpea haulms & 91.2 & 8.56 & 15.6 & 43.2 & 14.51 \\
\hline Cowpea pod shell & 90.7 & 8.95 & 9.20 & 65.5 & 9.07 \\
\hline Groundnut haulms & 90.5 & 13.4 & 18.1 & 54.0 & 16.30 \\
\hline Soybean haulms & 91.1 & 12.6 & 9.63 & 52.8 & 8.10 \\
\hline Soybean pod shell & 91.1 & 8.03 & 8.50 & 58.3 & 8.51 \\
\hline
\end{tabular}


D.B. M. HOUNDJO et al. / Int. J. Biol. Chem. Sci. 12(1): 519-541, 2018

Table 10: Dry matter composition and nutritive values of crop residues in Northern regions of Benin.

\begin{tabular}{|c|c|c|c|c|c|}
\hline & DM (\%) & Ash (\%) & $\mathrm{CP}(\%)$ & NDF (\%) & ME $(K J / k g D M)$ \\
\hline \multicolumn{6}{|l|}{ Cereal } \\
\hline Maize cob & 92.90 & 2.68 & 4.36 & 86.6 & 5.69 \\
\hline Maize husks & 92.50 & 6.88 & 5.84 & 79.9 & 6.90 \\
\hline Maize stalks & 92.20 & 6.79 & 4.07 & 87.7 & 5.26 \\
\hline Sorghum offal & 92.00 & 5.64 & 3.89 & 81.5 & 5.26 \\
\hline \multicolumn{6}{|l|}{ Legume } \\
\hline Cowpea haulms & 90.50 & 11.70 & 18.8 & 39.20 & 17.0 \\
\hline Cowpea pod shell & 93.60 & 4.060 & 8.84 & 68.70 & 8.63 \\
\hline Groundnut haulms & 90.40 & 10.10 & 13.90 & 51.70 & 12.6 \\
\hline Soybean haulms & 91.20 & 12.90 & 8.90 & 57.20 & 7.61 \\
\hline Soybean pod shell & 91.10 & 6.16 & 6.23 & 70.62 & 6.62 \\
\hline
\end{tabular}

$\mathrm{DM}=$ dry matter, $\mathrm{CP}=$ crude protein, $\mathrm{NDF}$ = neutral detergent fiber, $\mathrm{ME}$ = metabolizable energy; Source: (Koura, 2015).

Table 11: Agronomic characteristics of some grass forages adapted to Benin environment.

\begin{tabular}{|c|c|c|c|c|c|}
\hline Species & $\begin{array}{c}\text { Dry matter } \\
\text { yield (tons/ha) }\end{array}$ & Feeding values & Drought and defoliation tolerance & $\begin{array}{l}\text { Compatibility } \\
\text { with legumes }\end{array}$ & Source \\
\hline $\begin{array}{l}\text { Panicum } \\
\text { maximum }\end{array}$ & $3-15$ & $\begin{array}{l}5-13 \% \mathrm{CP}, 51-65 \% \text { digestibility, } 0,17 \% \mathrm{P}, \text { high palatability } \\
\text { before flowering and } \mathrm{LWG}^{*}=100-400 \mathrm{~kg} / \mathrm{ha} / \text { year }\end{array}$ & $\begin{array}{l}\text { Good tolerance to drought and very } \\
\text { high tolerance to defoliation }\end{array}$ & Very good & $\begin{array}{l}(1),(2),(3), \\
(4),(5)\end{array}$ \\
\hline $\begin{array}{l}\text { Andropogon } \\
\text { gayanus }\end{array}$ & $4-30$ & $\begin{array}{l}\text { 7-15\% CP, 63\% digestibility, high palatability and LWG + } \\
100-200 \mathrm{~kg} / \mathrm{ha} / \text { year }\end{array}$ & $\begin{array}{l}\text { Very high tolerance to drought and } \\
\text { good tolerance to defoliation }\end{array}$ & Medium to good & $\begin{array}{c}(1),(3),(6) \\
(7)\end{array}$ \\
\hline $\begin{array}{l}\text { Brachiaria } \\
\text { ruziziensis }\end{array}$ & $3-25$ & $\begin{array}{l}\text { 5-15\% CP, 55-75\% digestibility, very high palatability and } \\
\text { LWG* }^{*}>200 \mathrm{~kg} / \mathrm{ha} / \text { year }\end{array}$ & $\begin{array}{l}\text { Low tolerance to drought and } \\
\text { defoliation }\end{array}$ & low & $(1),(8),(9)$ \\
\hline
\end{tabular}

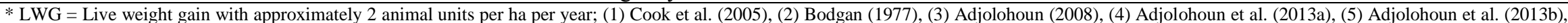

(6) Buldgen and Dieng (1997), (7) Toledo et al. (1990), (8) Adjolohoun et al. (2013d), (9) Milles et al. (1996). 
Table 12: Agronomic characteristics of some erect herbaceous legumes adapted to Benin environment.

\begin{tabular}{|c|c|c|c|c|c|}
\hline Species & $\begin{array}{c}\text { Dry matter } \\
\text { yield (tons/ha) }\end{array}$ & Feeding values & Drought and defoliation tolerance & $\begin{array}{l}\text { Compatibility with grasses } \\
\text { and nitrogen fixation }\end{array}$ & Source \\
\hline $\begin{array}{l}\text { Aeschynomene } \\
\text { histrix }\end{array}$ & $2-8$ & $\begin{array}{l}20 \% \mathrm{CP}, 53-66 \% \text { digestibility, very high } \\
\text { palatability and } \mathrm{LWG}^{*}>200 \mathrm{~kg} / \mathrm{ha} / \text { year }\end{array}$ & $\begin{array}{l}\text { Medium for drought and defoliation } \\
\text { tolerance }\end{array}$ & Good and $150 \mathrm{~kg} / \mathrm{ha} /$ year & $\begin{array}{l}(1),(2),(3),(4) \\
\quad(5),(6),(7)\end{array}$ \\
\hline A. americanum & $3-5$ & $\begin{array}{c}10-28 \% \mathrm{CP}, 60-70 \% \text { digestibility, very high } \\
\text { palatability and LWG }>200 \mathrm{~kg} / \mathrm{ha} / \text { year }\end{array}$ & $\begin{array}{l}\text { Moderate for drought and defoliation } \\
\text { tolerance }\end{array}$ & Good and $112 \mathrm{~kg} \mathrm{~N} / \mathrm{ha} /$ year & $(1),(8),(9),(10)$ \\
\hline A. indica & - & $\begin{array}{l}\text { Not sufficiently evaluated but may be } \\
\text { acceptable }\end{array}$ & $\begin{array}{l}\text { Low for drought and defoliation } \\
\text { tolerance }\end{array}$ & $\begin{array}{l}\text { Very good with } 100 \mathrm{~kg} \\
\mathrm{~N} / \mathrm{ha} / \text { year }\end{array}$ & $(1),(10),(12),(14)$ \\
\hline $\begin{array}{l}\text { Stylosanthes } \\
\text { fruticosa }\end{array}$ & $3-5$ & $8 \% \mathrm{CP}, 66 \%$ digestibility, high palatability & $\begin{array}{l}\text { Highly good but medium defoliation } \\
\text { tolerance }\end{array}$ & $\begin{array}{l}\text { Very good with more than } \\
80 \mathrm{~kg} \mathrm{~N} / \mathrm{ha} / \text { year }\end{array}$ & $(1),(2),(3),(4),(5)$ \\
\hline S. hamata & $1-6$ & $\begin{array}{c}\mathrm{CP}>17-24 \%, 66-72 \% \text { digestibility, very } \\
\text { good palatability }\end{array}$ & $\begin{array}{l}\text { Good for drought but low defoliation } \\
\text { tolerance }\end{array}$ & Good & $\begin{array}{l}\text { (1), (15), (16), (17), } \\
\quad(18),(19),(20)\end{array}$ \\
\hline
\end{tabular}

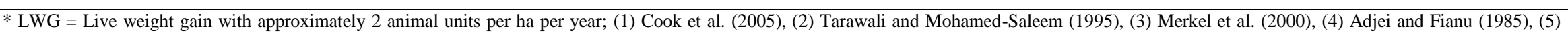

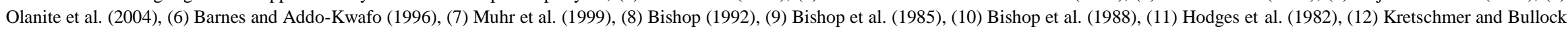
(1980), (14) Bielig (1997), (15) Roberge and Toutain (1999), (16) Cameron (1985), (17) English (1999), (18) Jones and Bunch (2003), (19) Jones and Jones (2003), (20) Loch and Ferguson (1999). 
Table 13: Agronomic characteristics of some climbing legumes adapted to Benin environment.

\begin{tabular}{|c|c|c|c|c|c|}
\hline Species & $\begin{array}{c}\text { Dry matter } \\
\text { yield (tons/ha) }\end{array}$ & Feeding values & $\begin{array}{c}\text { Drought and } \\
\text { defoliation tolerance }\end{array}$ & $\begin{array}{c}\text { Compatibility with grasses } \\
\text { and nitrogen fixation }\end{array}$ & Source \\
\hline $\begin{array}{l}\text { Centrosema } \\
\text { pubescens }\end{array}$ & $2-7$ & $\begin{array}{c}13-26 \% \mathrm{CP}, 54-65 \% \text { digestibility, } 0.15-0.21 \% \mathrm{P}, 0.5- \\
0.8 \% \mathrm{Ca}, 0.32 \% \mathrm{Mg}, 1.5 \% \mathrm{~K} \text {, high palatability and } \\
\text { LWG }>100-650 \mathrm{~kg} / \mathrm{ha} / \text { year }\end{array}$ & $\begin{array}{c}\text { Medium to good for } \\
\text { drought and defoliation } \\
\text { tolerance }\end{array}$ & $\begin{array}{l}\text { Very good and more than } 100 \\
\mathrm{~kg} \mathrm{~N} / \mathrm{ha} / \text { year }\end{array}$ & $\begin{array}{l}(1),(23),(8),(9), \\
\quad(10),(11)\end{array}$ \\
\hline $\begin{array}{l}\text { Pueraria } \\
\text { phaseoloides }\end{array}$ & $1-6$ & $\begin{array}{l}10-20 \% \mathrm{CP} \text {, more than } 65 \% \text { palatability and LWG }> \\
200 \mathrm{~kg} / \mathrm{ha} / \text { year }\end{array}$ & $\begin{array}{l}\text { Medium and moderately } \\
\text { tolerant to defoliation }\end{array}$ & $\begin{array}{l}\text { Medium compatibility and } \\
\text { more than } 250 \mathrm{~kg} \mathrm{~N} / \mathrm{ha} / \text { year }\end{array}$ & (1) (22) \\
\hline $\begin{array}{l}\text { Mucuna } \\
\text { pruriens }\end{array}$ & $2-10$ & $\begin{array}{l}11-26 \% \mathrm{CP}, 60-65 \% \text { digestibility, high mineral content, } \\
\text { medium to high palatability and LWG is good. }\end{array}$ & Annual plant & $\begin{array}{l}\text { Very good and more than300 } \\
\mathrm{kg} \mathrm{N} / \mathrm{ha} / \text { year }\end{array}$ & $\begin{array}{l}(1),(13),(14) \\
(15),(16),(17)\end{array}$ \\
\hline
\end{tabular}

al. (1982), (13) Buckles et al. (1998), (14) Bielig (1997), (15) Roberge and Toutain (1999), (16) Cameron (1985), (17) English (1999).

Table 14: Agronomic characteristics of some ligneous forage legumes adapted to Benin environment.

\begin{tabular}{|c|c|c|c|c|c|}
\hline Species & $\begin{array}{c}\text { Dry matter } \\
\text { yield (tons/ha) }\end{array}$ & Feeding values & $\begin{array}{c}\text { Drought and defoliation } \\
\text { tolerance }\end{array}$ & $\begin{array}{l}\text { Compatibility with grasses } \\
\text { and nitrogen fixation }\end{array}$ & Source \\
\hline $\begin{array}{l}\text { Cajanus } \\
\text { cajan }\end{array}$ & $2-25$ & $\begin{array}{c}10-25 \% \text { CP, palatability increases with plant age, and } \\
\text { LWG } 200-500 \mathrm{~kg} / \mathrm{ha} / \text { year. }\end{array}$ & $\begin{array}{l}\text { Very good for drought but } \\
\text { low defoliation tolerance }\end{array}$ & $\begin{array}{l}\text { Very good with more than } \\
250 \mathrm{~kg} \mathrm{~N} / \mathrm{ha} / \text { year }\end{array}$ & $\begin{array}{l}(1),(24),(8),(9), \\
(10)\end{array}$ \\
\hline $\begin{array}{l}\text { Leucaena } \\
\text { leucocephala }\end{array}$ & $1-33$ & $\begin{array}{c}25-30 \% \mathrm{CP}, 55-70 \% \text {, very high palatability, } 0.2-0.3 \% \\
\mathrm{P}, 0.8-1.9 \% \mathrm{Ca}, 0.01-0.02 \% \mathrm{Na} \text { and LWG : 200-1700 } \\
\mathrm{kg} / \mathrm{ha} / \text { year }\end{array}$ & $\begin{array}{l}\text { Very good for drought and } \\
\text { defoliation tolerance }\end{array}$ & $\begin{array}{l}\text { Very good with more than } \\
200 \mathrm{~kg} \mathrm{~N} / \mathrm{ha} / \text { year }\end{array}$ & $\begin{array}{l}(1),(11),(12) \\
(13),(14),(15) \\
(16)\end{array}$ \\
\hline $\begin{array}{l}\text { Gliricidia } \\
\text { sepium }\end{array}$ & $2-20$ & $\begin{array}{c}\text { 18-30\% CP, 60-65\% digestibility, low palatability and } \\
\text { high toxicity, increases } 25 \% \text { LWG. }\end{array}$ & $\begin{array}{l}\text { Very good for drought and } \\
\text { defoliation tolerance }\end{array}$ & $\begin{array}{l}\text { Very good with more than } \\
100 \mathrm{~kg} \mathrm{~N} / \mathrm{ha} / \text { year }\end{array}$ & $\begin{array}{l}(1),(17),(18), \\
(19),(20),(21)\end{array}$ \\
\hline
\end{tabular}

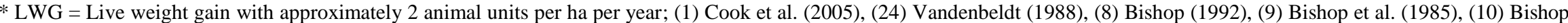

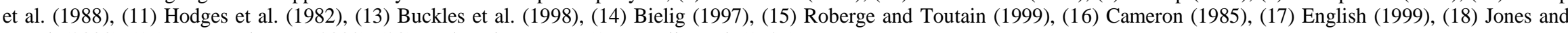
Bunch (2003), (19) Jones and Jones (2003), (20) Loch and Ferguson (1999), Ella et al. (1989). 


\section{Conclusion}

In tropical areas such as Benin the growth of the ruminant livestock improvement has been impeded by several constraints such as low feed supply in quantity and quality, low crop-livestock integration, low level of management practices, lack of improved breeding stock, disease, inadequate stock water, poor marketing and lack of capital. Zootechnical performances of animals are very low. To solve this problem cultivated forage legumes can provide cheap highquality feed, which can greatly enhance the productivity of traditional agricultural systems.

\section{COMPETING INTERESTS}

Authors have declared that no competing interests exist.

\section{AUTHORS' CONTRIBUTIONS}

This work was carried out in collaboration between all authors. DDMH designed the study, performed documentation research, was involved in data collection, and wrote the first draft of the manuscript. SA and others managed on data collection, evaluation and interpretations. All authors read and approved the final manuscript.

\section{REFERENCES}

Adam KS, Boko M. 1983. Le Bénin. EDICEF: Paris ; 95.

Adandedjan C. 1993. Essais et développement des cultures fourragères. Rapport d'activité mai 1993, Projet de Développement de la Production Animale, Cotonou, Bénin, pp. 4-5.

Adjei MB, Fianu FK. 1985. The effect of cutting interval on the yield and nutritive value of some tropical legumes on the coastal grassland of Ghana. Trop. Grass., 19: 164-171.

Adjolohoun S. 2008. Yield, nutritive value and effects on soil fertility of forage grasses and legumes cultivated as ley pastures in the Borgou region of Benin. Thèse pour l'obtention du Diplôme de
Doctorat en Sciences agronomiques et Ingénierie biologique. Faculté Universitaire des Sciences Agronomiques de Gembloux. Belgique. $101 \mathrm{p}$.

Adjolohoun S. 1992. Contribution à l'Etude des Systèmes d'Elevage et Gestion Agro-Pastorale du Terroir: Cas de Village de Tchankuehoun dans la SousPréfecture de Matéri (BENIN). Mémoire d'Ingénieur Agronome. Faculté des Sciences Agronomiques, Université d'Abomey-Calavi, 169p.

Adjolohoun S. 1994. Diagnostic zootechnique des systèmes de production dans les régions voisines des Fermes du Projet Développement Production Animale (PDPA). Rapport d'activité, 100p.

Adjolohoun S, Dahouda M, Adandedjan C, Toleba SS, Kindomihou V, Sinsin B. 2013a. Evaluation of biomass production and nutritive value of nine Panicum maximum ecotypes in Central region of Benin. African Journal of Agricultural Research, 8(17): 1661-1668. http://www.academicjournals.org/AJAR

Adjolohoun S, Dahouda M, Adandedjan C, Toleba SS, Houinato M, Nonfon R, Sinsin B. 2013b. Diversité et caractérisation morphologique des écotypes de l'espèce fourragère Panicum maximum au Bénin. International Journal of Biological and Chemical Sciences, $\quad$ 6(5): 2043-2054. http://ajol.info/index.php/ijbcs

Adjolohoun S, Bindelle J, Adandedjan C, Toleba SS, Houinato M, Sinsin B. 2013c. Growth and forage production of four Arachis pintoi (Kaprovickas \& Gregory) genotypes in two contrasting ecological regions of Benin (West Africa). International Journal of Agriculture Innovations and Research, 2(2): 2319-1473.

Adjolohoun S, Bindelle J, Adandedjan C, Toleba SS, Houinato M, Kindomihou V, Nonfon WRV, Sinsin B. 2013d. Influence de l'écartement et de la fertilisation azotée sur le rendement et la 
qualité des semences de Brachiaria ruziziensis en climat tropical subhumide. Fourrages, 216: 339-345. http://www.afpf-asso.org/index/action/ page/id/3/title/la-revue-fourrages

Akinfemi A, Adua MM, Adu OA. 2012. Evaluation of nutritive values of tropical feed sources and by-products using in vitro gas production technique in ruminant animals. Emirates Journal of Food and Agriculture, 24(4): 348-353.

ASECNA 2010. Statistiques météorologiques. Agence pour la Sécurité de la Navigation Aérienne en Afrique et à Madagascar.

Atchadé C, Sidi B. 1990. Etude des pâturages naturels et propositions de gestion. PDPA, Direction d'Elevage, 50p.

Attoh-Kotoku V. 2011. Feeding two nerica rice straw varieties to sheep: effects of supplementation with leguminous foliages on digestibility, nutrient utilization and growth performance. Journal of Science and Multidisciplinary Research, 4: 59-67.

Ayantunde AA, Delfosse P, Fernandez-Rivera S, Gerard B, Dan-Gomma A. 2007. Supplementation with groundnut haulms for sheep fattening in the West African Sahel. Tropical Animal Health Production, 39: 207-216.

Azuka CV, Igué AM, Diekkrüger B, Igwe CA. 2015. Soil survey and soil classification of the Koupendri catchment in Benin, West Africa. African Journal of Agricultural Research, 10(42): 3938-3951.

Babatounde S, Oumorou M, Tchabi VI, Lecomte T, Houinato M, Adandedjan C. 2010. Ingestion volontaire et préférences alimentaires chez des moutons Djallonké nourris avec des graminées et des légumineuses fourragères tropicales cultivées au Bénin. Int. J. Biol. Chem. Sci., 4(4): 1030-1043. DOI: http://dx.doi.org/10.4314/ijbcs.v7i6.23

Barnes P, Addo-kwafo A. 1996. Evaluation of introduced forage accessions for fodder production at a subhumid site in southern Ghana. Trop. Grass., 30: 422-425.
Bielig LM. 1997. Chromosome numbers in the forage legume genus, Aeschynomene L. Sabrao Journal, 29: 33-39.

Bishop HG. 1992. Aeschynomene americana L. In Plant Resources of South-East Asia No. 4, Forages, Mannetje L, Jones RM (eds). Pudoc Scientific Publishers: Wageningen, the Netherlands; 37-38.

Bishop HG, Ludke DH, Rutherford MT. 1985. Glenn jointvetch: A new pasture legume for Queensland coastal areas. Queens. Agric. J., 111: 241-245.

Bishop HG, Pengelly BC, Ludke DH. 1988. Classification and description of a collection of the legume genus, Aeschynomene. Trop. Grass., 22: 160175.

Bogdan AV. 1977. Tropical Pastures and Fodder Plants (grasses and legumes). Longman : London, New York; 475.

Buckles D, Triomphe B, Sain G. 1998. Cover Crops in Hillside Agriculture. Farmer Innovation with Mucuna. IDRC and CIMMYT: Ottawa, Canada; 222.

Buldgen A, Michiels B, Adjolohoun S, Babatoundé S, Adandedjan C. 2001. Production and nutritive value of grasses cultivated in the coastal area of Benin. Trop. Grass., 35: 43-47.

Buldgen A, Dieng A. 1997. Andropogon Gayanus var. Bisquamulatus. Une Culture Fourragère pour les Régions Tropicales. Les Presses Agronomiques de Gembloux: Gembloux, Belgique; 171.

Commission de Pédologie et Cartographie des Sols. 1967. Classification Française des Sols. Travaux C.P.C.S. Grignon, France: ENSA, $96 \mathrm{p}$.

Cameron DG. 1985. Tropical and subtropical legumes 5. Siratro pasture (Macroptilum atropurpureum): the most widely planted subtropical legume. Queens. Agri. J. 111: 45-49.

Carr PM, Poland WW, Tisor LJ. 2005. Natural reseeding by forage legumes following wheat in western North Dakota. Agron. J., 97: 1270-1277. DOI: 
http://dx.doi.org/10.2134/agronj2005.00 7

Cook BG, Pengelly BC, Brown SD, Donnelly JL, Eagles DA, Franco MA, Hanson J, Mullen BF, Partridge IJ, Peters M, Schultze-Kraft R. 2005. The Production of Tropical Forages: An alternative selection tool. Available at <http://www.tropicalforages.info > accessed on [20/07/2017]

DE. 2013. Direction de l'Elevage, Etats des ressources génétiques animales au Bénin. Annuaire statistique, $55 \mathrm{p}$.

Diarra A, Barbier B, Zongo B, Yacouba H. 2017. Impact of climate change on cotton production in Burkina Faso. Afr. J. Agric. Res., 12(7): 494-501. DOI: http://dx.doi.org/10.5897/AJAR2015.107 63

Doussoh AM, Dangou JS, Houedjissin SS, Assogba AK, Ahanhanzo C. 2017. Analyse des connaissances endogènes et des déterminants de la production de la patate douce [Ipomoea batatas (L.)], une culture à haute valeur socioculturelle et économique au Bénin. Int. J. Biol. Chem. Sci., 10(6): 2596-2616, DOI: http://dx.doi.org/10.4314/ijbcs.v10i6.16.

DSA. 2017. Direction des Statistiques Agricoles. Les statistiques agricoles $\mathrm{du}$ Bénin, $100 \mathrm{p}$.

Ella A, Jacobsen C, Stür WW, Blair G. 1989. Effect of plant density and cutting frequency on the productivity of four tree legumes. Trop. Grass., 23: 28-34.

Enbakom HW, Feyssa DH, Takele S. 2017. Impacts of deforestation on the livelihood of smallholder farmers in Arba Minch Zuria Woreda, Southern Ethiopia. Afr. J. Agric. Res., 12(15): 1293-1305.

DOI: http://dx.doi.org/10.5897/AJAR2015.101 23

English BH. 1999. Macroptilum atropurpureum in Australia. In Forage seed Production (vol 2) Tropical and Subtropical Species, Loch DS, Ferguson JE (eds). CABI Publishing, Wallingford, UK ; 407-412.
FAO (Food and Agriculture Organisation). 1965. Guidelines for Soil Description. FAO Flat: Paris. France; 22.

FAO. 2014. Faostat Database Results. Food and Agriculture Organisation of the United Nations: Rome, Italy.

Flávia MAG, Henrique ZB, Luciana G, Alessandra AG, Karina B, Waldssimiler TM, Linda MP, Alberto Nagib VM. 2017. The utilization of tropical legumes to provide nitrogen to pastures: A review. Afri. J. Agric. Res., 12(2): 85-92.

Floret C, Pontannier R. 1999. La jachère en Afrique tropicale vol. 1. Les actes du congrès. Rôles, aménagement, alternatives. Actes du séminaire international, Dakar, Sénégal. Avril $1999,860 \mathrm{p}$.

Gbanboché AB. 2005. Performances zootechniques et paramètres génétiques des ovins Djallonké au Bénin. Thèse de Doctorat en Sciences vétérinaires Orientation Santé et Productions animales. Université de liège. Belgique, $220 \mathrm{p}$.

Gimenes FMA, Barbosa HZ, Gerdes L, Giacomini AA, Batista K, de Mattos WT, Premazzi LM, Miguel ANV. 2017. The utilization of tropical legumes to provide nitrogen to pastures: A review. Afr. J. Agric. Res., 12(2): 85-92. DOI: http://dx.doi.org/10.5897/AJAR2016.118 93

Gnikplekpo ELR. 2016. Les systèmes d'élevage bovins face à la variabilité climatique et aux activités anthropiques le long du littoral du Bénin: stratégies d'adaptation et durabilité. Mémoire d'Etudes Approfondies (DEA). Faculté des Sciences Agronomiques.

Guèye EF. 1998. Village egg and fowl meat in Africa. Regional report. World's Poultry Sci. J., 54: 73-86.

Hodges EM, Kretschmer AE, Mislevy P, Roush RD, Ruelke OC, Snyder GH. 1982. Production and utilization of the tropical legume Aeschynomene (Aeschynomene americana L.). Circular 
$S$-290. Institute of Food and Agricultural Sciences, University of Florida.

Houinato M. 2001. Phytosociologie, écologie, productivité et capacité de charge des formations végétales pâturées dans la région des Monts-kouffé (Bénin). Thèse de Doctorat. Fac. Sc. Lab. Bot. Syst. et Phyt. Uni.Lib. Bruxelles, Belgique, 219p.

IGN. 2017. Institut de Géographie National. Carte du Bénin: Divisions administratives et Agroécologiques. 1 p.

INSAE. 2008. Statistiques économiques/ Production agricole. http://www.insaebj.org/production-agricole.html.

Consulted on December 12, 2015.

INSAE. 2015. Statistiques économiques/ Production agricole. http://www.insaebj.org/production-agricole.html.

Consulted on December 12, 2015.

Jones RM, Bunch GA. 2003. Experiences with farm pastures at the former CSIRO Samford Research Station, south-east Queensland, and how these relate to results from 40 years of research. Trop. Grass., 37: 151-164.

Jones RM, Jones RJ. 2003. Effect of stocking rates on animal gain, pasture yield and composition, and soil properties from setaria-nitrogen and setaria-legume pastures in coastal south-east Queensland. Trop. Grass., 37: 65-83.

Kagoné H. 2000. Gestion durable des écosystèmes pâturés en zone nordsoudanienne du Burkina Faso. Thèse de doctorat, Faculté Universitaire des Sciences Agronomiques de Gembloux. Belgique. 236 p. + annexes.

Klein HD, César J. 1999. Plantes fourragères et fertilité du sol. In Culture Fourragères Tropicales, Robertge G, Toutain B (eds). CIRAD ; 321-357.

Kouelo FA, Houngnandan P, Dedehouanou H, Tossou R, Orou Bello DO, Joël Bekou KA, Tchetangni AY. 2016. Soil conservation practices in three watersheds of Benin: Farmers' cropping systems characterization. Afr. J. Agric. Res., 11(7): 507-515. DOI:
http://dx.doi.org/10.5897/AJAR2015.102 77

Kouelo FA, Houngnandan P, Gerd D. 2013. Contribution of seven legumes residues incorporated into soil and NP fertilizer to maize yield, nitrogen use efficiency and harvest index in degraded soil in the center of Benin. Int. J. Biol. Chem. Sci., 7(4): 2468-2489. DOI: http://dx.doi.org/10.4314/ijbcs.v7i6.23

Koura B. 2015. Improvement of animal productivity by using crop residues in integrated crop-livestock systems in Benin. $\mathrm{PhD}$ thesis. University of Abomey-Calavi. Abomey-Calavi. 186 p.

Koutika LS, Sanginga N, Vanlauwe B, Weise S. 2002. Chemical properties of soil organic matter assessment under fallow systems in the forest margins benchmark. Soil Biol. Biochem., 34: 757765. DOI: http://dx.doi.org/10.1016/ S0038-0717 (02)00005-6

Kretschmer AE, Bullock RC. 1980. Aeschynomene spp.: Distribution and potential use. Proceedings of the Soil and Crop Science Society of Florida, 39: 145-152.

Lesse DPAA. 2015. Gestion et modélisation de la dynamique des parcours de transhumance dans un contexte de variabilités climatiques au nord-est du Bénin. Thèse de Doctorat. Université d'Abomey-Calavi. Abomey-Calavi. 305 p.

Loch DS, Ferguson JE. 1999. Forage Seed Production (vol 2), Tropical and Subtropical Species. CAB International: Oxon, UK; 479 p.

MAEP. 2010. Ministry of Agriculture, Livestock and fisheries of Benin. Rapport d'Activités.

Mannetje L'T. 2000. Potencial y perspectivas para la sustentabilidad de las pasturas tropicales. In Producción de Leche y Carne en el Trópico con Base en Pastoreo, Castillo GE, Jarillo RJ, Concha OS (eds). Centro de Enseñanza, Investigación y Extensión en Ganadería Tropical, FMVZ, UNAM, Unión 
Ganadera Regional del Norte de Veracruz, Tuxpam de Rodríguez Cano, Veracruz ; $1-15$.

McIntire J, Bourzat D, Pingali P. 1992. Crop Livestock Interaction in Sub-Saharan Africa. World Bank: Washington DC, USA; 246.

Merkel U, Peters M, Tarawali SA, SchultzeKraft R, Berner DK. 2000. Characterization of a collection of Aeschynomene histrix in subhumid Nigeria. J. Agri. Sci., 134: 293-304.

Milles JW, Maass BL, Valle CB, Kumble V. 1996. Brachiaria: Biology, Agronomy and Improvement. CIAT: Brasil, publication No. 259, Cali. Colombia; 288.

Minson DJ. 1981. Nutrition difference between tropical and temperate pastures. In. World Animal Science, Morley FHW (ed). Elsevier Scientific Publishing Company: Amsterdam.

Montcho M, Babatounde S, Aboh AB, Bahini MJD, Chrysostome CAAM, Mensah GA. 2016. Caractéristiques physiques et nutritionnelles des blocs multi nutritionnels fabriqués à partir des sousproduits agricoles et agroindustriels du Bénin. Int. J. Biol. Chem. Sci., 10(6): 2485-2496. DOI: http://dx.doi.org/ 10.4314/ijbcs.v10i6.7

Muhr L. 1998. Potential of forage legumes on follow land for enhanced forage production and soil fertility in croplivestock farming systems of subhumid West Africa. PhD Thesis. Univ. Hohenheim, Hohenheim, Germany.

Muhr L, Peters M, Tarawali SA, SchultzeKraft R. 1999. Forage legumes for improved fallows in agropastoral systems of subhumid West Africa. III. Nutrient import and export by forage legumes and their rotational effects on subsequent maize. Trop. Grass., 33: 245256.

Nikiema A. 2005. Agroforestry parkland species diversity: uses and management in semi-arid West Africa (Burkina Faso).
$\mathrm{PhD}$ thesis. Wageningen University. Wageningen, p.102.

Nonfon R. 2015. La filière de production du porc local au Bénin : l'amélioration de sa productivité par l'alimentation. Thèse de Doctorat. Faculté Universitaire des Sciences Agronomiques de Gembloux. Belgique, $236 \mathrm{p}$.

Ojokoh AO, Odesanya OF. 2016. Fermentation of cassava (Manihot esculenta) and ripe plantain peels (Musa paradisiaca) in the production of animal feed. Journal of Advances in Microbiology, 1(2): 1-15. DOI: http://dx.doi.org/10.9734/JAMB/2016/30 354

Olanite JA, Tarawali SA, Akan'ova ME. 2004. Biomass yield, quality and acceptability of selected grass-legume mixtures in the moist savanna of West Africa. Trop. Grass., 38: 117-128.

Olounladé P. 2011. Etude phytochimique et propriétés anthelminthiques de Newbouldia laevis et de Zanthoxylum zanthoxylö̈des sur des nématodes gastrointestinaux animaux et humains. Thèse de Doctorat. Université d'AbomeyCalavi. Abomey-Calavi. 273 p.

Peters M, Lascano CE. 2003. Forage technology adoption: linking on-station research with participatory methods. Trop. Grass., 37: 197-203.

PNUD. 2000. Rapport annuel sur le développement humain durable du Bénin.

Roberge G, Toutain B. 1999. Choix des plantes fourragères. In Cultures Fourragères Tropicales, Roberge G, Toutain B (eds). CIRAD; 147-184.

Saidou A. 2006. Converging strategies by farmers and scientist to improve soil fertility and enhance crop production in Benin. PhD thesis. Wageningen University. Wageningen, p. 225.

Savadogo M, Zemmelink G, Van Keulen H, Nianogo AJ. 1999. Contribution of crop residues to ruminant feeding in different agroecological zones of Burkina Faso. 
Rev. Elev. Méd. Vét. Pays Trop., 52(3-4): 255-262.

Sinsin B, Oloulotan S, Oumorou M. 1989. Les pâturages de saison sèche de la zone soudanienne du Nord-Est du Bénin. Rev. Elev. Méd. Vét. Pays Trop., 42: 283-288. DOI: $\quad$ http://dx.doi.org/10.19182/ remvt.8859

Smith AJ. 1990. The Tropical Agriculturalist. Poultry CTA-Macmillan Press London, 106: 179-188.

Somé NA, Traoré K, Traoré O, Tassembedo M. 2007. Potentiel des jachères artificielles à Andropogon spp, dans l'amélioration des propriétés chimiques et biologiques des sols en zone soudanienne (Burkina Faso). Biotechnol. Agron. Soc. Environ., 11: 245-252.

Tarawali G, Mohamed-Saleem MA. 1995. The role of legume fallows in supplying improved feed and recycling nitrogen in subhumid Nigeria. In Livestock and Sustainable Nutrient Cycling in Mixed Farming Systems of Sub-Saharan Africa ( Vol 2). Technical Papers, Tarawali G, Mohamed-Saleem MA, Powell JM, Fernandez RS, Williams TO, Renard C. (eds). Proceedings, Addis Ababa, Ethiopia, 22-26 November 1993.

Toledo JM, Vera R, Lascano C, Lenne JM. 1990. Andropogon gayanus Kunth. In A
Grass for Tropical Acid Soils. CIAT publication: Cali, Colombia; 381.

Vandenbeldt JR. 1988. Cajanus cajan: it's more than just a pulse. NFT Highlights, NFTA, 88-06, p. 1-2

Ye L, Lata JC, Masse D, Nacro HB, Sébastien Barot S. 2017. Effets du pâturage sur la biomasse herbacée et sur des paramètres chimiques et biologiques des sols dans une savane arbustive au Burkina Faso. Int. J. Biol. Chem. Sci., 10(6): 25392554. DOI: http://dx.doi.org/10.4314/ ijbcs.v10i6.11.

Youssouf I, Lawani M. 2002. Les sols béninois: classification dans la réference mondiale. Quatorzième réunion du souscomité Ouest et Centre Africain de corrélation des sols pour la mise en valeur des terres. Bénin, Abomey-Calavi 9-13 octobre 2000. Abomey-Calavi, Bénin. FAO.

Zoumarou NW, Bagnan MA, Akossou AYY, Kanlindogbe CB. 2016. Caractérisation morphologique d'une collection de fruits d'anacardier provenant de la commune de Parakou (Bénin). Int. J. Biol. Chem. Sci., 10(6): 2413-2422. DOI: http://dx.doi.org/10.4314/ijbcs.v10i6.1 